Analytical Methods in Environmental Chemistry Journal Vol 2 (2019) 65-76

Research Article, Issue 2
Analytical Methods in Environmental Chemistry Journal
AMECJ

\title{
The use of zinc metalloporphyrin grafted magnetic nanoparticles for the removal of sulfate ions from wastewaters \\ Tahereh Poursaberi ${ }^{\mathrm{a}}$ and Ali Akbar Miran Beigi ${ }^{\mathrm{b}, *}$
}

a Analytical Research Group, Research Institute of Petroleum Industry, Tehran, Iran

${ }^{b}$ Oil Refining Research Division, Research Institute of Petroleum Industry, Tehran, Iran

A R T I C L E I N F O:

Received 2 March 2019

Revised form 22 Apr 2019

Accepted 16 May 2019

Available online 16 Jun 2019

Keywords:

Magnetic nanoparticles

Water samples

Sulfate removal

Zinc (II) porphyrin

Nanosorbent

\begin{abstract}
A B S T R A C T
This study investigates an application of zinc metalloporphyrin grafted $\mathrm{Fe}_{3} \mathrm{O}_{4}$ nanoparticles as a new adsorbent for removal of sulfate ions from wastewaters. The modification of magnetite nanoparticles was conducted by 3-aminopropyltriethoxysilane followed by zinc (II) porphyrin in order to enhance the removal of sulfate ions. Moreover, Fourier Transform Infrared Spectroscopy (FT-IR), X-ray diffraction (XRD), Transmission Electron Microscopy (TEM) and Scanning Electron Microscopy (SEM) were used to characterize the synthesized nanosorbent. The effect of important experimental factors such as $\mathrm{pH}$, contact time, sorbent dosage and some co-existing anions present in aqueous solutions were investigated. Under optimal conditions (i.e. contact time: $30 \mathrm{~min}, \mathrm{pH}$ : 6.5 and nanosorbents dosage: $100 \mathrm{mg}$ ) for a sulfate sample $\left(50 \mathrm{~mL}, 50 \mathrm{mgL}^{-1}\right)$, the percentage of the extracted sulfate ions was $94.5 \%$. Regeneration of sulfate adsorbed material could be possible by $\mathrm{NaOH}$ solution and the modified magnetic nanosorbent exhibited good reusability. The proposed system can provide a fast and efficient removal of the sulfate ion by using just an external magnetic field. In addition, the competitive adsorption tests verified that this system has good adsorption selectivity for sulfate ion. Finally, the synthesized sorbent was successfully applied for treating a wastewater sample from glass industry..
\end{abstract}

\section{Introduction}

Sulfate is a common constituent of many natural waters and wastewaters [1], which it is present as a dissolved compound in seas and oceans or as insoluble salt (e.g., gypsumlayers). Industrial wastewaters are responsible for most anthropogenic emissions of sulfate into the environment. Domestic sewage typically contains between 20 and $500 \mathrm{mg}$ $\mathrm{L}^{-1}$ sulfate [2] while certain industrial effluents may contain several thousands of milligrams per

Corresponding Author: Ali Akbar Miran Beigi *

E-mail: amiranbeigi@yahoo.com; miranbeigiaa@ripi.ir https://doi.org/10.24200/amecj.v2.i2.62 liter. The main source of sulfate in the laboratory wastewaters is the use of sulfuric acid in many routine chemical analyses. Sulfur compounds are also present in wastewaters used in the research activities such as those from the pulp and paper industry, the food processing industry, and the photographic sector, among others [3].

The damage which is caused by sulfate emissions is not direct, since sulfate is a chemically inert, nonvolatile, and non-toxic compound. However, high sulfate concentrations can unbalance the natural sulfur cycle [1, 2], and also endanger human health when excessive ingestion. The accumulation of 
sulfate-rich sediments in lakes, rivers and sea may cause the release of toxic sulfides that can provoke damages to the environment [4]. The World Health Organization (WHO) has established the maximum tolerable level of sulfate in water as $500 \mathrm{mg}$ $\mathrm{L}^{-1}[5]$. The current U.S. EPA national Secondary Maximum Contaminant Level for sulfate, based on organoleptic effects, is $250 \mathrm{mg} \mathrm{L}^{-1}$ [6].

A number of methods are currently used to promote the removal of dissolved sulfate. They include reversed osmosis, electrodialysis, or nanofiltration, which are expensive, can be poisoned by impurities, and require a post-treatment of the brine [2]. In addition, established methods for removal of sulfate from industrial effluents include chemical precipitation, biological treatment and adsorption technologies. Chemical precipitation, for example, to add barium or calcium salts, is rapid and effective, but it may produce another kind of pollution and secondary treatment for solid phase is necessary [1]. Removal of sulfate by sulfatereducing bacteria is another alternative; however, the efficiency of biological treatment is susceptible to environmental conditions because the growth requirements of this microbial are relatively rigid [7]. Adsorption method may be preferred for their rapid and high selectivity, and sulfur can be recovered.

More recently, the use of NPs for sample extraction is gaining researchers interest [8-16]. Compared with micrometer-sized particles used in the SPE, the NPs offer a multitude of benefits that make it a better choice. They have a significantly higher surface area-to-volume ratio and a short diffusion route, resulting in a higher extraction capacity; rapid dynamics of extraction and its higher extraction efficiencies [17, 18]. Also, the main advantage of magnetic nanoparticles is their separation by application of external magnetic field. In addition, combination of the molecular scale recognition and nano scale surface modification creates a powerful tool for the development of selective separation systems. Depending on the usage, surface modification can be performed by physical / chemical sorption or surface coating of specific ligands [19-23].

Supramolecular chemistry of anions has been widely studied and created a lot of artificial anionophores [24, 25] among them; in addition, metalloporphyrins (MP) are well known for their ability as anion carriers. The coordinating site of MPs is an acidic metal and the anion recognition is the result of specific anion coordination with this central metal ion [26]. Previously, it has been reported by us that the application of magnetic nanoparticles modified by $\mathrm{Zr}(\mathrm{IV})$ porphyrin and oxovanadium(IV) porphyrin for removal of fluoride and nitrate respectively [27, 28].

Herein, we have combined the sulfate selectivity of zinc (II) porphyrin with the advantages of magnetic nanoparticles has been combined by us to fabricate a new kind of magnetic nanosized sorbent with high affinity toward sulfate ion and good magnetic separability. The effect of $\mathrm{pH}$, contact time, nanosorbent dosage and some co-existing anions present in aqueous solutions on sulfate removal efficiency were investigated.

\section{Experimental procedure}

\subsection{Materials}

Ferric chloride hexahydrate, ferrous chloride tetrahydrate, APTES, dichloromethane (DCM), $\mathrm{N}, \mathrm{N}$ dimethylformamide (DMF), dicyclohexylcarbodiimide (DCHC), methanol, ammonia, sodium salts of indicated anions were all analytical grade from Merck Chemical Co. Meso-Tetrakis (4-carboxyphenyl) porphyrinato zinc (II) (ZnTCPP) was obtained by metallation of the free ligand porphyrin tetrakis (4-carboxyphenyl) porphine $\mathrm{H}_{2}$ (TCPP) (Aldrich)

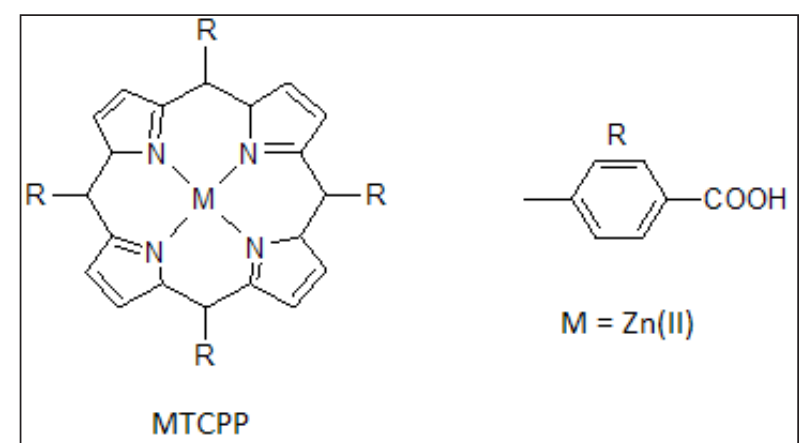

Fig. 1. Schematic representation of the Zinc (II) porphyrin used in this work. 
according to the methods described in the literature [29]. Schematic of the Zinc (II) porphyrin is shown in Figure 1.

\subsection{Equipments}

The morphology and dimension of $\mathrm{Fe}_{3} \mathrm{O}_{4}$ /APTES/ ZnTCPP were examined by transmission electron microscope (TEM) using Zeiss 900 TEM at a voltage of $80 \mathrm{kV}$. Size and morphology of the nanosorbent were investigated by Tescan Mira LMU SEM. The phase purity was characterized by X-ray powder diffraction (XRD) (PW-1840 diffractometer from Philips Co) using $\mathrm{Cu}-\mathrm{K} \alpha$ radiation ( $\lambda=1.54178 \AA$ ). Ion chromatography (IC) determinations were carried out in a S 1122 Sykam ion chromatograph. In addition, $\mathrm{pH}$ measurements were performed with a Metrohm $691 \mathrm{pH}$ meter. FTIR spectra were recorded on a Vertex 70 FT-IR spectrophotometer from Bruker Co. using standard $\mathrm{KBr}$ pellet technique.

\subsection{Sorbent preparation}

\subsubsection{Synthesis of $\mathrm{Fe}_{3} \mathrm{O}_{4}$ nanoparticles}

The chemical co-precipitation method was used in the preparation of the $\mathrm{Fe}_{3} \mathrm{O}_{4} \mathrm{NPs}$ [30]. First, for preparing a stock solution, $10.4 \mathrm{~g}$ of $\mathrm{FeCl}_{3} \cdot 6 \mathrm{H}_{2} \mathrm{O}$, with $4.0 \mathrm{~g}$ of $\mathrm{FeCl}_{2} \cdot 4 \mathrm{H}_{2} \mathrm{O}$ and $1.7 \mathrm{~mL}$ of $\mathrm{HCl}$ $\left(12 \mathrm{~mol} \mathrm{~L}^{-1}\right)$ were mixed and dissolved in $50 \mathrm{~mL}$ of deionized water in a beaker which was then degassed using nitrogen gas for $20 \mathrm{~min}$ before use. Simultaneously, $500 \mathrm{~mL}$ of $1.5 \mathrm{~mol} \mathrm{~L}^{-1} \mathrm{NaOH}$ solution was degassed (for $15 \mathrm{~min}$ ) and heated to $80{ }^{\circ} \mathrm{C}$ in a reactor. The stock solution was then added dropwise using a dropping funnel for 30 min under nitrogen gas protection and vigorously stirring (1000 rpm) using a glassware stirrer. During the whole process, the solution temperature was maintained at $80^{\circ} \mathrm{C}$, and nitrogen gas was used to prevent the intrusion of oxygen. After the reaction, the obtained $\mathrm{Fe}_{3} \mathrm{O}_{4}$ NPs precipitate was separated from the reaction medium by using a magnetic field, and then washed four times with $500 \mathrm{~mL}$ of deionized water. Finally, $\mathrm{Fe}_{3} \mathrm{O}_{4}$ nanoparticles were dried.

\subsubsection{Modification of $\mathrm{Fe}_{3} \mathrm{O}_{4}$ nanoparticles with APTES groups}

$\mathrm{Fe}_{3} \mathrm{O}_{4} /$ APTES nanoparticles were synthesized via the reaction of APTES and hydroxyl groups on the surface of magnetite. $2.3 \mathrm{~g}$ of $\mathrm{Fe}_{3} \mathrm{O}_{4}$ nanoparticles were dispersed in $100 \mathrm{~mL}$ of ethanol by sonication for about $1 \mathrm{~h}$. Then under continuous mechanical stirring, $20.34 \mathrm{~mL}$ of APTES was added dropwise to the suspension. The reaction mixture was kept at $40{ }^{\circ} \mathrm{C}$ for $20 \mathrm{~h}$ under nitrogen atmosphere with vigorous mechanical stirring. The prepared APTES nanoparticles were collected with a magnet, and washed with ethanol and deionized water. Finally,

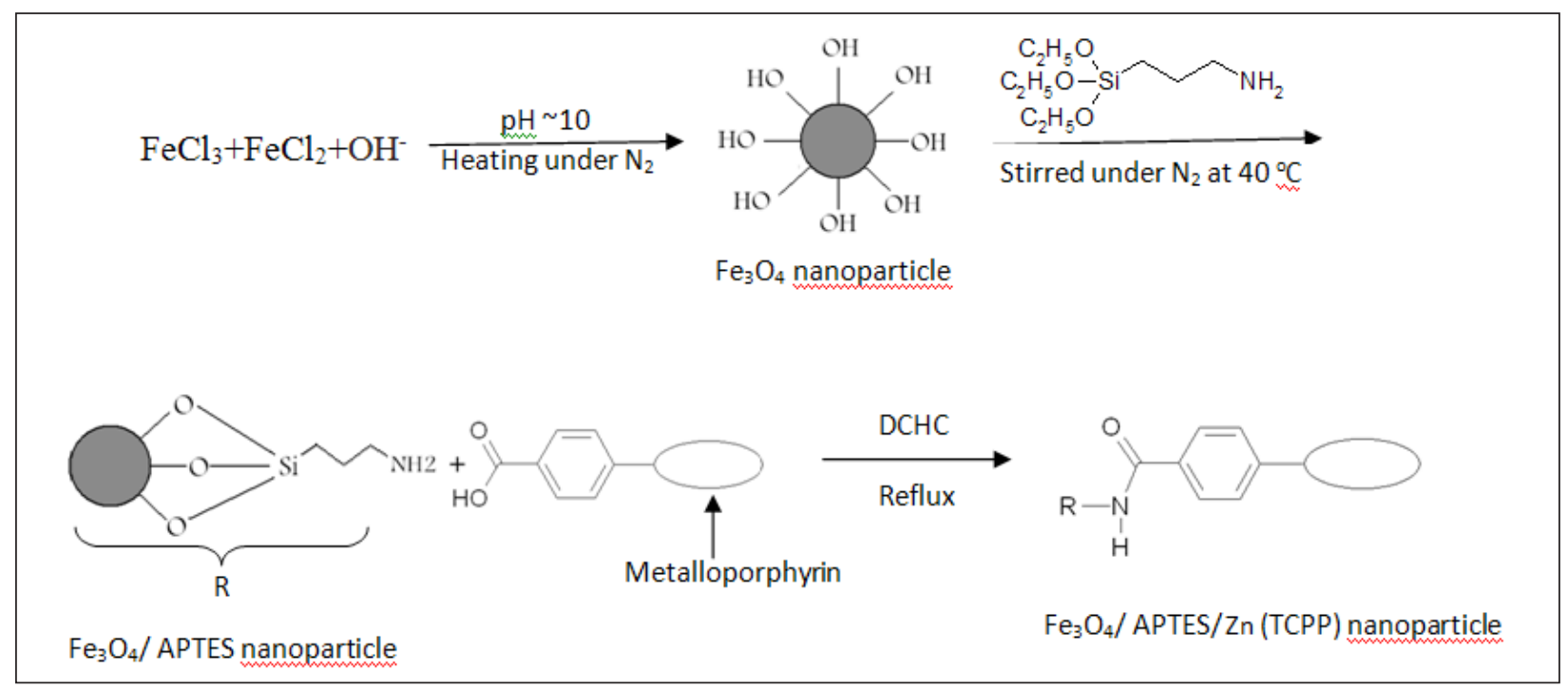

Fig. 2. A scheme of the magnetite synthesis and surface modification process using APTES followed by metalloporphyrin insertion. 
$\mathrm{Fe}_{3} \mathrm{O}_{4} /$ APTES nanoparticles were dried under vacuum at $50{ }^{\circ} \mathrm{C}$.

\subsubsection{Grafting of $Z n(T C P P)$ groups at the surface of $\mathrm{Fe}_{3} \mathrm{O} / \mathrm{APTES}$}

Functionalization of the modified nanoparticles was carried out by suspension of $\mathrm{Fe}_{3} \mathrm{O}_{4}$ /APTES and DCHC in DMF under nitrogen [31]. Then $\mathrm{Zn}$ (TCPP) was dissolved in DMF and added to the suspension. The mixture was refluxed at $140{ }^{\circ} \mathrm{C}$ for $8 \mathrm{~h}$. In order to prevent the presence of volatile dimethylamine, a product of DMF decomposition, a high flux of nitrogen is recommended. After reaction, the solid $\mathrm{Fe}_{3} \mathrm{O}_{4} / \mathrm{APTES} / \mathrm{Zn}$ (TCPP) nanoparticles were separated magnetically and washed with DMF, $\mathrm{CH}_{2} \mathrm{Cl}_{2}$, and methanol to remove non-covalently bonded porphyrins from $\mathrm{Fe}_{3} \mathrm{O}_{4} /$ APTES. A scheme of the magnetite synthesis and surface modification process is shown in Figure 2.

\subsection{Removal of sulfate ions by $\mathrm{Fe}_{3} \mathrm{O}_{4}$ APTES/Zn (TCPP)}

Adsorption of sulfate by $\mathrm{Fe}_{3} \mathrm{O}_{4} /$ APTES/ZnTCPP has been studied in batch experiments. A known amount of nanosorbent $(100 \mathrm{mg})$ was mixed with $50 \mathrm{ml}$ of $50 \mathrm{mgL}^{-1}$ aqueous sulfate solution and was shaken at room temperature with $200 \mathrm{rpm}$ for a $30 \mathrm{~min}$. The sorbent was separated before measurement. The residual sulfate concentration of aqueous solution was determined by ion chromatography. The sulfate removal efficiency was calculated according to Eq. (1):

Sulfate removal efficiency $(\%)=\left[\frac{C_{0}-C_{r}}{C_{0}}\right] \times 100$

where $\mathrm{C}_{\mathrm{o}}$ and $\mathrm{C}_{\mathrm{r}}$ are the initial and final concentrations of the sulfate ion before and after the sorption, respectively.

\section{Results and discussion}

\subsection{Characterization of the synthesized nanosorbent}

\subsubsection{X-ray powder Diffraction (XRD)}

$\mathrm{XRD}$ analysis was used to investigate the crystalline structure of synthesized nanoparticles (Figure 3).

The Joint Committee on Powder Diffraction Standards (JCPDS) reference pattern of magnetite (No. 19-629) was used for comparison. As seen, the XRD pattern of magnetite nanoparticles was in good agreement with that of the standard $\mathrm{Fe}_{3} \mathrm{O}_{4}$ structure. The same set of characteristic peaks were also observed for $\mathrm{Fe}_{3} \mathrm{O}_{4} /$ APTES and $\mathrm{Fe}_{3} \mathrm{O}_{4} /$ APTES/ZnTCPP, indicating the stability of the

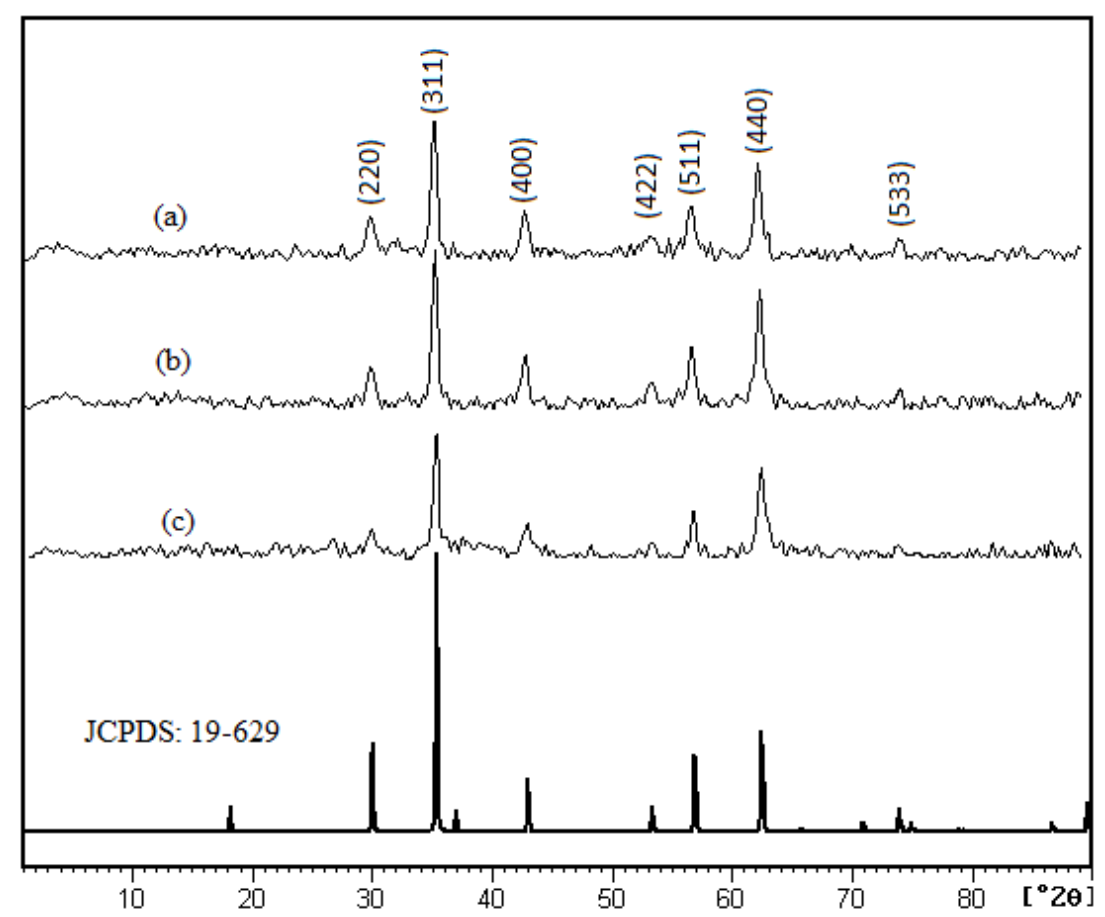

Fig. 3. XRD patterns of $\mathrm{Fe}_{3} \mathrm{O}_{4}(\mathrm{a}), \mathrm{Fe}_{3} \mathrm{O}_{4} / \mathrm{APTES}(\mathrm{b})$, and $\mathrm{Fe}_{3} \mathrm{O}_{4} / \mathrm{APTES} / \mathrm{Zn}(\mathrm{TCPP})$ (c). 
crystalline phase of $\mathrm{Fe}_{3} \mathrm{O}_{4}$ nanoparticles during functionalization and revealed that the APTES coating and metalloporphyrin grafting did not result in the phase change of $\mathrm{Fe}_{3} \mathrm{O}_{4}$.

The Single formula given by Debye Scherre (Eq. 2) can be used to calculate the crystalline size from the available XRD data. The average size of the $\mathrm{Fe}_{3} \mathrm{O}_{4}$ nanoparticles using Debye Scherre was about $27 \mathrm{~nm}$.

$$
\mathrm{D}=\mathrm{K} \lambda / \beta \cos (\theta)
$$

\subsubsection{Scanning Electron Microscopy (SEM)}

The particle size and morphological characteristics of the magnetite nanoparticles, before and after surface modification, were investigated by using SEM (Fig. 4). As can be seen from figure 4a, the bare magnetic nanoparticles show spherical shape with some aggregates due to the lack of any repulsive force between the magnetite nanoparticles. This is mainly due to the nano-size of the $\mathrm{Fe}_{3} \mathrm{O}_{4}$, which is about $27 \mathrm{~nm}$. After APTES introduction (Fig. 4b), particles with an approximate spherical shape and an average diameter of $30 \mathrm{~nm}$ were observed. This may be considered as indirect evidence that the magnetite core of the APTES magnetite particles consisted of a single magnetite crystallite with a typical diameter of $27 \mathrm{~nm}$; and that the difference of $3 \mathrm{~nm}$ corresponds the APTES-coating. After metalloporphyrin immobilization (Fig. 4c), the dispersion of particles were improved greatly. It can easily be explained by the electrostatic repulsion force and steric hindrance between the metaloporphyrin on the surface of $\mathrm{Fe}_{3} \mathrm{O}_{4}$ nanoparticles. Figure $4 \mathrm{c}$ shows that the morphology of the functionalized magnetic nanoparticles almost maintains the original state.

\subsubsection{Transmission Electron Microscopy (TEM)}

The introduction of $\mathrm{Zn}$ (TCPP) into the magnetite nanoparticles was evident from TEM results. The dark nano- $\mathrm{Fe}_{3} \mathrm{O}_{4}$ cores surrounded by a grey shell could be observed in Figure 5. Moreover, the
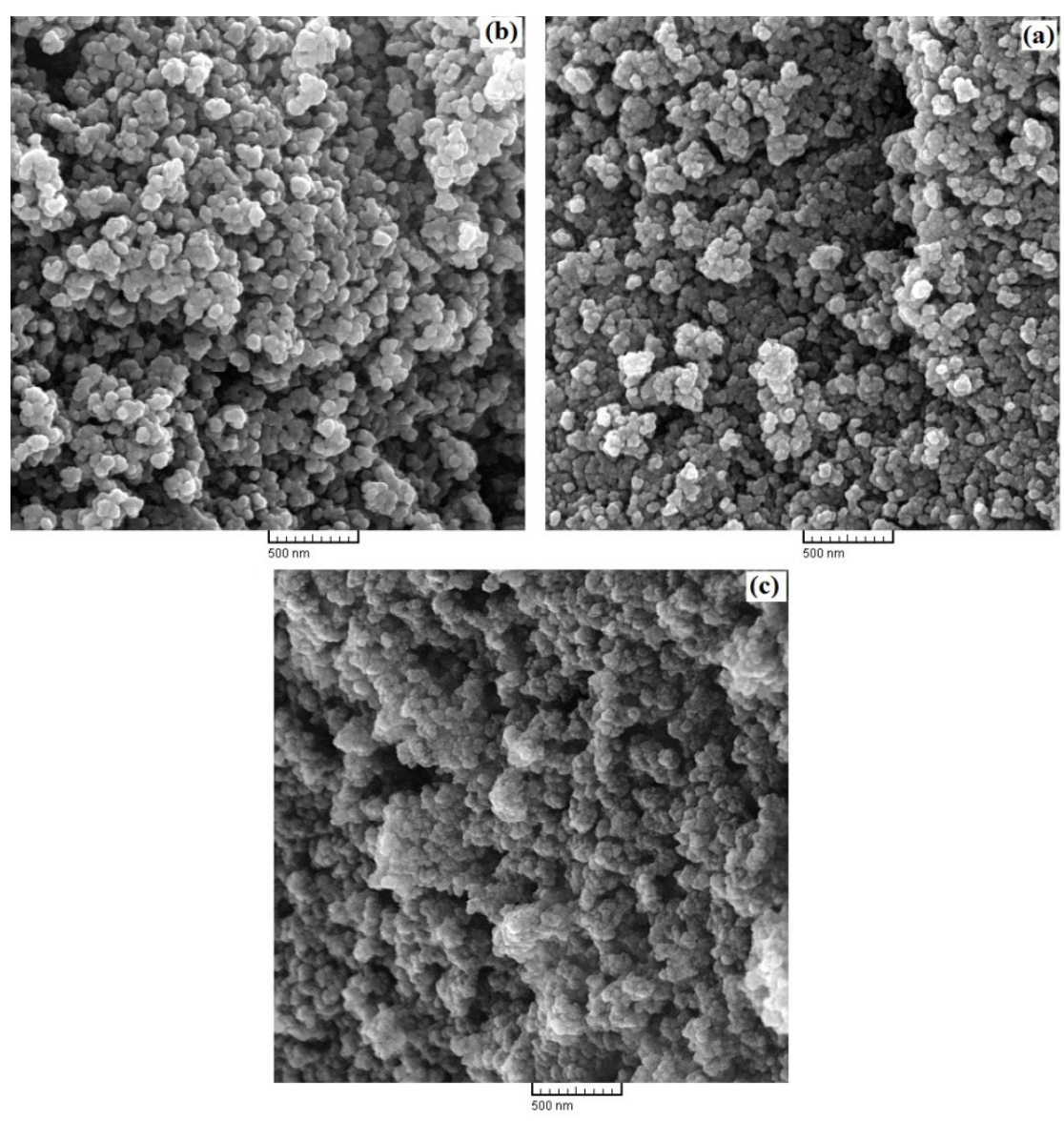

Fig. 4. SEM images of Fe3O4 (a), Fe3O4/APTES (b) and Fe3O4/APTES/Zn(TCPP) (c). 


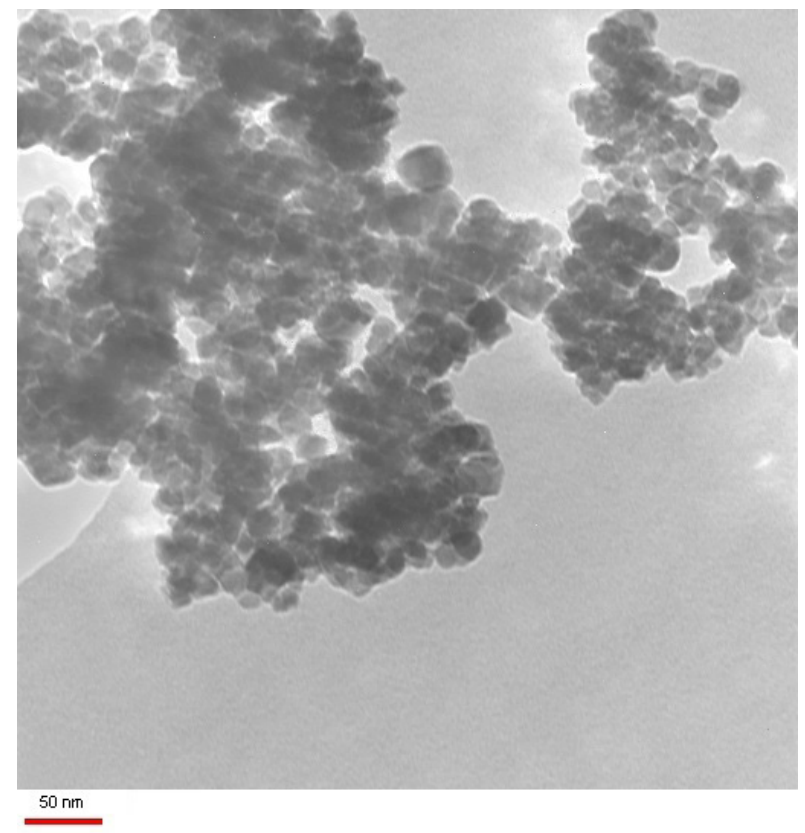

Fig. 5. TEM micrograph of $\mathrm{Fe}_{3} \mathrm{O}_{4} / \mathrm{APTES} / \mathrm{Zn}$ (TCPP) nanosorbents.

particles have special characteristics such as an approximate spherical shape and an average size of $45 \mathrm{~nm}$, which their characteristics complement the SEM data.

\subsubsection{FT-IR spectrum}

FT-IR is a reliable technique for the monitoring of the variations in the functional groups. Thereofre, the structures of the synthesized nanosorbent $\left(\mathrm{Fe}_{3} \mathrm{O}_{4} / \mathrm{APTES} / \mathrm{Zn}(\mathrm{TCPP})\right)$ were characterized by
FTIR spectroscopy (Fig. 6). Fe-O stretching band at $580 \mathrm{~cm}^{-1}$ is the characteristic peak of magnetite. Moreover, absorption bands at 2925 and 2860 $\mathrm{cm}^{-1}$ assigned to stretching vibration of $\mathrm{C}-\mathrm{H}$ bond of the propyl amine group. The silica network adheres to the particle surface via $\mathrm{Fe}-\mathrm{O}-\mathrm{Si}$ bond. The introduction of APTES to the surface of $\mathrm{Fe}_{3} \mathrm{O}_{4}$ nanoparticles was confirmed by the bands around 1012 and $1115 \mathrm{~cm}^{-1}$ from the $\mathrm{SiO}-\mathrm{H}$ and $\mathrm{Si}-\mathrm{O}-\mathrm{Si}$ groups. A band at $3430 \mathrm{~cm}^{-1}$ can be ascribed to the $\mathrm{N}-\mathrm{H}$ stretching vibration. A peak at $1647 \mathrm{~cm}^{-1}$ relating to the amide group stretching band, which proves that the metalloporphyrin can be covalently attached to the amine groups of APTES through the formation of a stable amide bond. The spectrum also showed the $\mathrm{C}=\mathrm{C}$ stretching vibrations of carbon-carbon bonds of the aromatic ring about $1500 \mathrm{~cm}^{-1}$.

\subsection{Adsorption experiments}

\subsubsection{Optimization of the parameters}

\subsubsection{Effect of the solution $\mathrm{pH}$}

It is well known that $\mathrm{pH}$ is one of the most important factors which affect the sorption process. Experiments were performed to find the optimum $\mathrm{pH}$ on the sorption of sulfate ions onto proposed nanosorbents using different $\mathrm{pH}$ values changing from 4.0 to 9.0 .

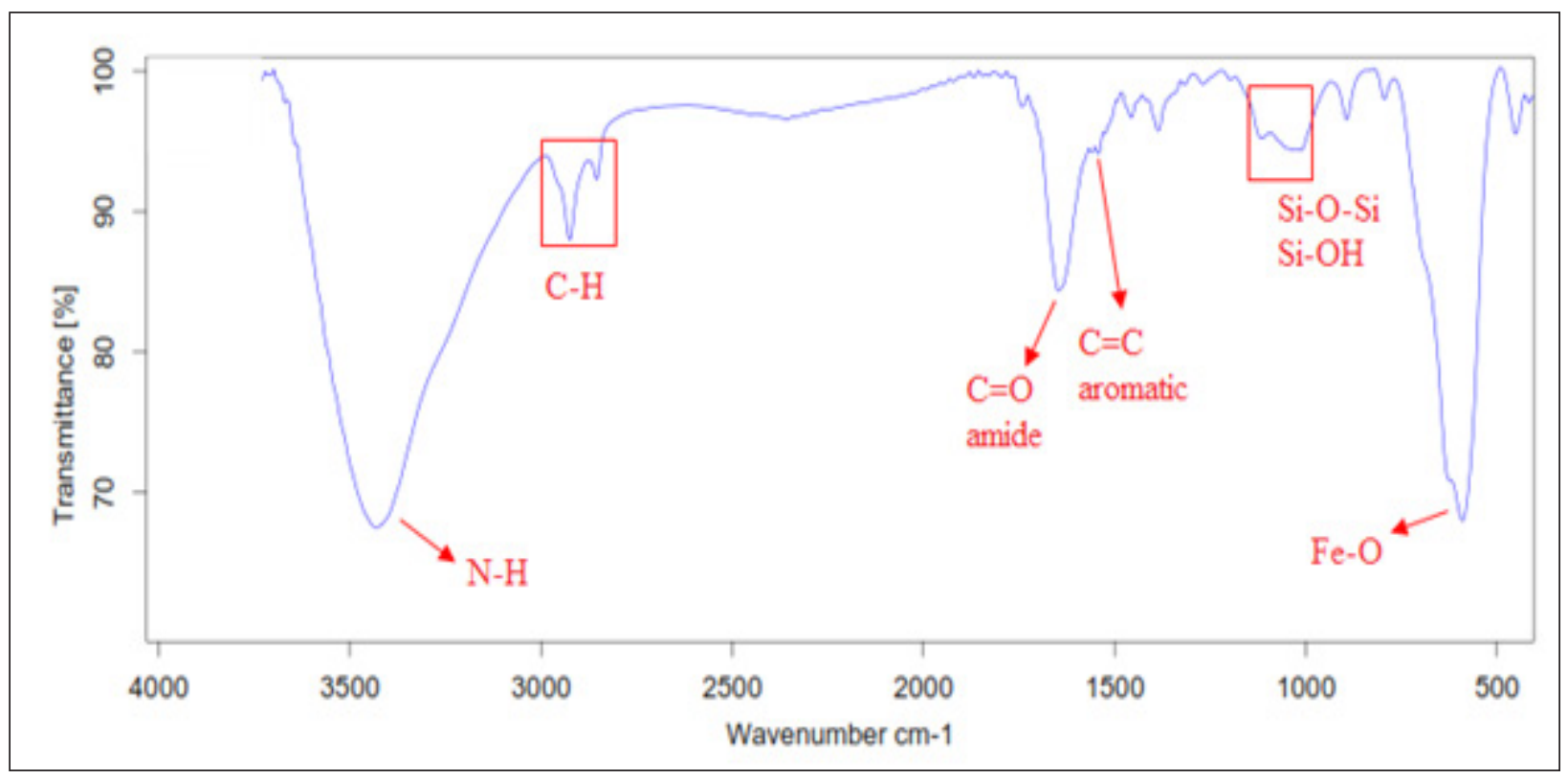

Fig. 6. FTIR spectra of $\mathrm{Fe}_{3} \mathrm{O}_{4} / \mathrm{APTES} / \mathrm{Zn}$ (TCPP) nanoadsorbents. 


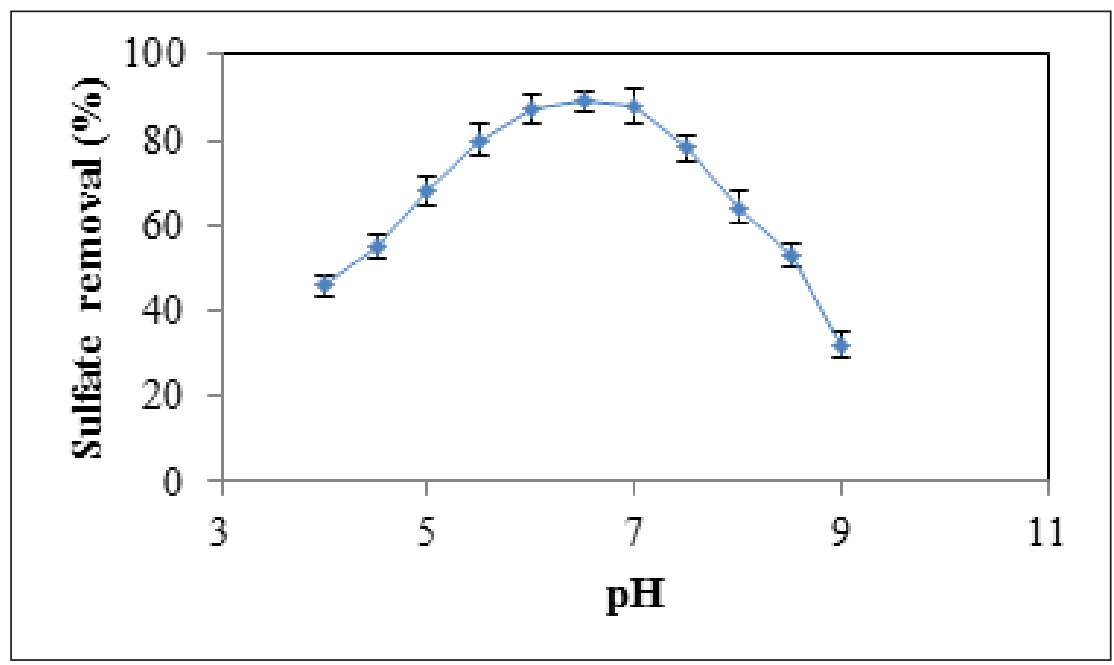

Fig. 7. The $\mathrm{pH}$ influence on the removal efficiency of sulfate (amount of adsorbent: $100 \mathrm{mg}$; sulfate concentration: 50 $\left.\mathrm{mg} \mathrm{L}^{-1}\right)$.

As presented in Figure 7, while the sulfate removal depends on the $\mathrm{pH}$ of the sample, there is only a slight variation of the sulfate removal percentage with the $\mathrm{pH}$ values in the $6.0-7.0 \mathrm{pH}$ range. In the acidic region the sulfate removal is decreased as a result of partial demetallation of the metalloporphyrin complex during the contact with the low $\mathrm{pH}$ test solution $[32,33]$. At high $\mathrm{pH}$ values, sulfate and $\mathrm{OH}^{-}$ions are in competition to coordinate to the central metal ion (Zinc) of the porphyrin and therefore the sorption of nitrite ions is decreased [34]. Therefore, $\mathrm{pH}=6.5$ was selected for all subsequent experiments.

\subsubsection{Effect of the contact time}

Contact time studies were performed to obtain the optimum time with the maximum amount of sulfate removed. The adsorption of sulfate onto nanoadsorbents was monitored for $120 \mathrm{~min}$. Sulfate was adsorbed onto nanosorbents quickly, and equilibrium was achieved within $30 \mathrm{~min}$ and thereafter remains constant (Fig. 8). Therefore, the time of $30 \mathrm{~min}$ was chosen as optimum value for all subsequent experiments.

\subsubsection{Effect of the adsorbent dosage}

To find the optimum amount of nanosorbents which can remove sulfate ions from aqueous solution, a batch-mode sorption study was performed using various amounts $(25-250 \mathrm{mg})$ of $\mathrm{Fe}_{3} \mathrm{O}_{4} / \mathrm{APTES} /$ $\mathrm{Zn}$ (TCPP) nanosorbents. The sulfate removal efficiency as a function of nanosorbents dosage

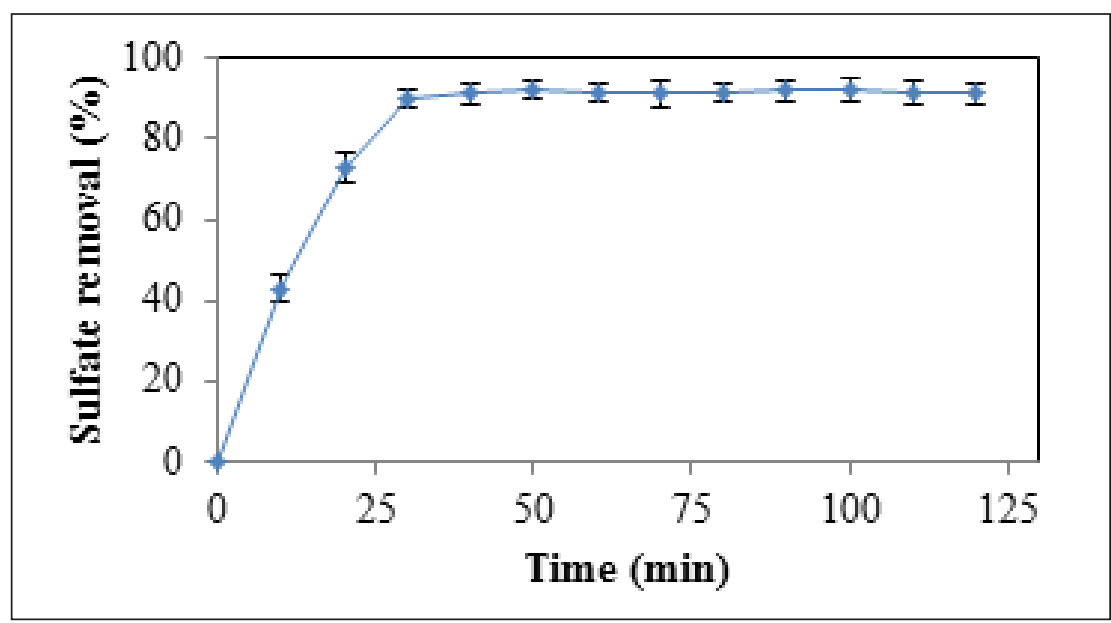

Fig. 8. Effect of contact time on the adsorption of sulfate by modified nanosorbent ( $\mathrm{pH}$ of the solution: 6.5 , amount of adsorbent: $100 \mathrm{mg}$; sulfate concentration: $50 \mathrm{mg} \mathrm{L}^{-1}$ ). 


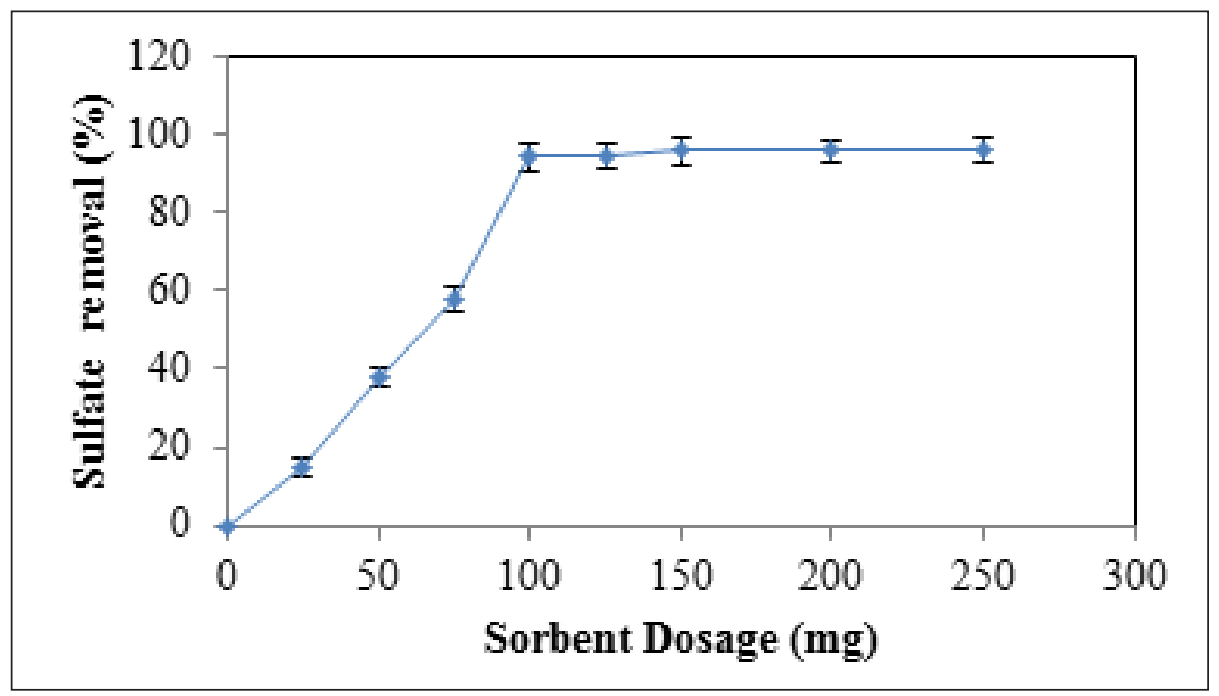

Fig. 9. Effect of nanosorbents dosage on the sulfate removal by modified nanosorbent ( $\mathrm{pH}$ of the solution: 6.5 , contact time: $30 \mathrm{~min}$, sulfate concentration: $50 \mathrm{mg} \mathrm{L}^{-1}$ ).

is presented in Figure 9. Moreover, it is evident that the percent of sulfate removal increased with the increase of the sorbent dosage which is due to the fact that a greater amount of sorbent implies a greater amount of available binding sites. As seen in Figure 9, the percent removal reached steady state value after $100 \mathrm{mg}$ of $\mathrm{Fe}_{3} \mathrm{O}_{4}$ /APTES/ $\mathrm{Zn}$ (TCPP) nanosorbents for $50 \mathrm{~mL}$ of aqueous solution containing $50 \mathrm{mg} \mathrm{L}^{-1}$ sulfate ion. Therefore, in all the experiments, $0.1 \mathrm{~g}$ of the nanoadsorbents was fixed as the optimum dose.

\subsubsection{Removal studies}

\subsubsection{Removal of sulfate from spiked sample}

In order to evaluate the performance of the synthesized nanosorbent for sulfate removal, solidphase extraction was used under optimal conditions. The deionized water was spiked with sulfate ion to make a $50.0 \mathrm{mg} \mathrm{L}^{-1}$ solution. The batch adsorption experiment was carried out on $50 \mathrm{~mL}$ of this spiked sample under optimal conditions; i.e. contact time: 30 minutes, $\mathrm{pH}=6.5$ and sorbent dosage: $100 \mathrm{mg}$. It was found that the sulfate content decreased from $50.0 \mathrm{mg} \mathrm{L}^{-1}$ to $2.75 \mathrm{mg} \mathrm{L}^{-1}(94.5 \pm 2.7 \%$ removal efficiency, $(\mathrm{n}=5))$.

\subsubsection{Effect of co-existing anions}

Depending on the water source, more than one anion might be present. By considering the competition for the binding sites between sulfate ions and such anions, they may affect the extraction efficiency of the proposed nanosorbent and might interfere with the removal efficiency of sulfate. In due course, prior to the application of proposed method on real samples, it is essential to investigate the effect of some of the interfering ions on the recovery percentage of sulfate; therefore, the adsorption of sulfate ion is tested in the presence of spiked known amounts of interfering ions. The tolerance limit was defined as the amount of the foreign ion causing a change of $\pm 5 \%$ in the removal efficiency. As seen from figure 10, the removal percentage of sulfate was remained within the tolerance limit in the presence of fifty-fold of nitrite and nitrate and one hundred-fold of fluoride, chloride and bromide concentrations. These experimental results indicated that the method has a good tolerance toward matrix interferences.

\subsubsection{Regeneration of the used sorbent}

In the evaluation of the performance of the sorbents, regeneration is an important factor to make an economic process. Moreover, in this work, $\mathrm{NaOH}$ was chosen as the stripping reagent for the recovery of sulfate ions from the adsorbents. The concentration of the $\mathrm{NaOH}$ solution was optimized, and the results indicated that the highest recovery was obtained by using $\mathrm{NaOH} 0.1 \mathrm{M}$ solution (Fig. 11). 


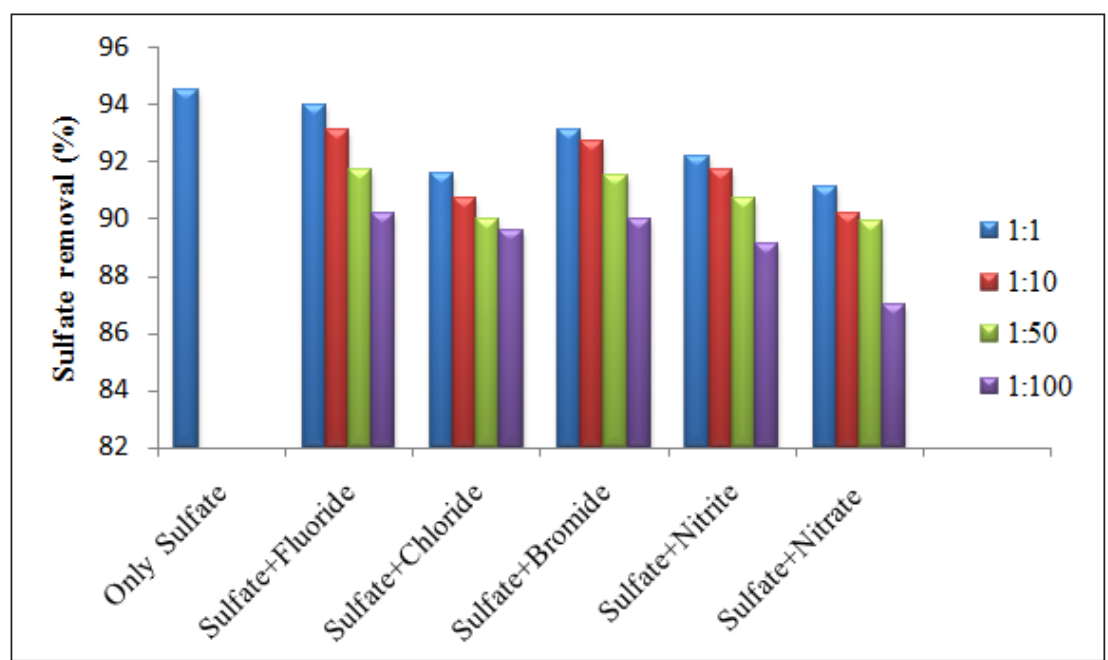

Fig. 10. Effect of co-existing anions on removal efficiency of a $50 \mathrm{mg} \mathrm{L}^{-1}$ sulfate ion.

Regeneration performance of $\mathrm{Fe}_{3} \mathrm{O}_{4}$ /APTES/ ZnTCPP was tested for repeatedly use in practice applications. The spent $\mathrm{Fe}_{3} \mathrm{O}_{4} / \mathrm{APTES} / \mathrm{ZnTCPP}$ was immersed in $10 \mathrm{ml} 0.1 \mathrm{M} \mathrm{NaOH}$ solution and shaken for $30 \mathrm{~min}$ to desorb the loaded sulphate ions. Then the exchanger was separated from the $\mathrm{NaOH}$ solution with aid of magnet and washed with deionized water until the eluent was up to a neutral $\mathrm{pH}$.

\subsubsection{Reusability of the recycled sorbent}

After the first regeneration, nanosorbent was used in the followed adsorption test to record its sulphate adsorption efficiency again. This adsorption and desorption cycle was repeated five times. As seen in Figure 12, after four sorption-desorption cycles, the efficiency of nanosorbent for the sulfate removal was not significantly reduced (not more than 5\%), but at fifth run, an $8 \%$ decrease in its performance was observed; therefore, the desorption limit for sulfate was four cycles. It could be concluded that the chemical bonding between $\mathrm{Zn}$ porphyrin group and magnetite plays the major role in retaining the capacity of the $\mathrm{Fe}_{3} \mathrm{O}_{4} / \mathrm{APTES} / \mathrm{Zn}$ (TCPP) nanosorbents.

\subsubsection{Removal of sulfate from real sample}

Considering the practical applicability of proposed nanosorbent for removal of sulfate from real samples, it was also tested with wastewater obtained

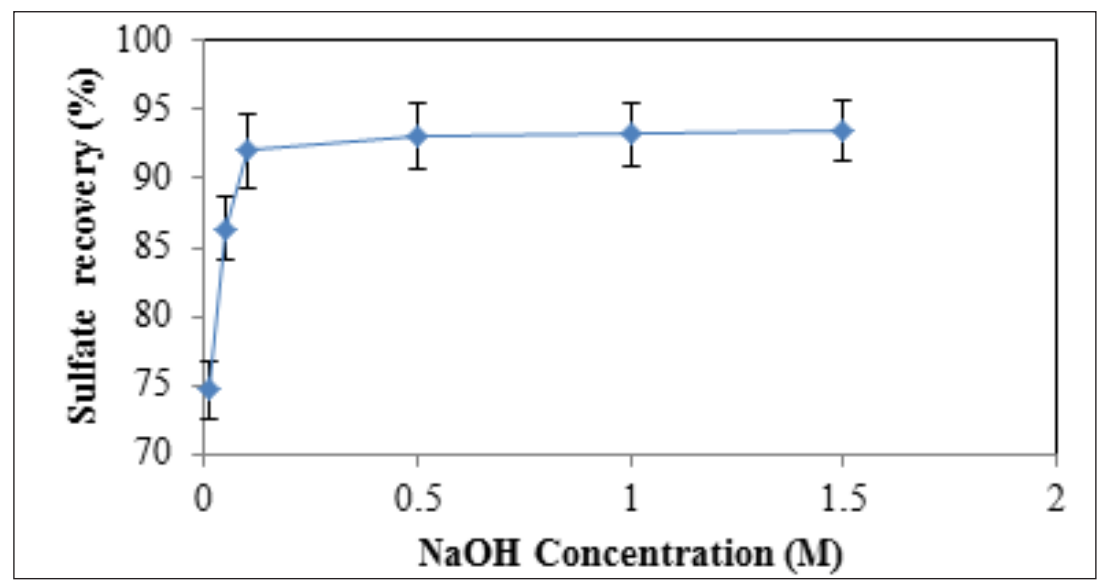

Fig. 11. The effect of $\mathrm{NaOH}$ concentration as desorbing eluent on the recovery percentage of sulfate ion. 


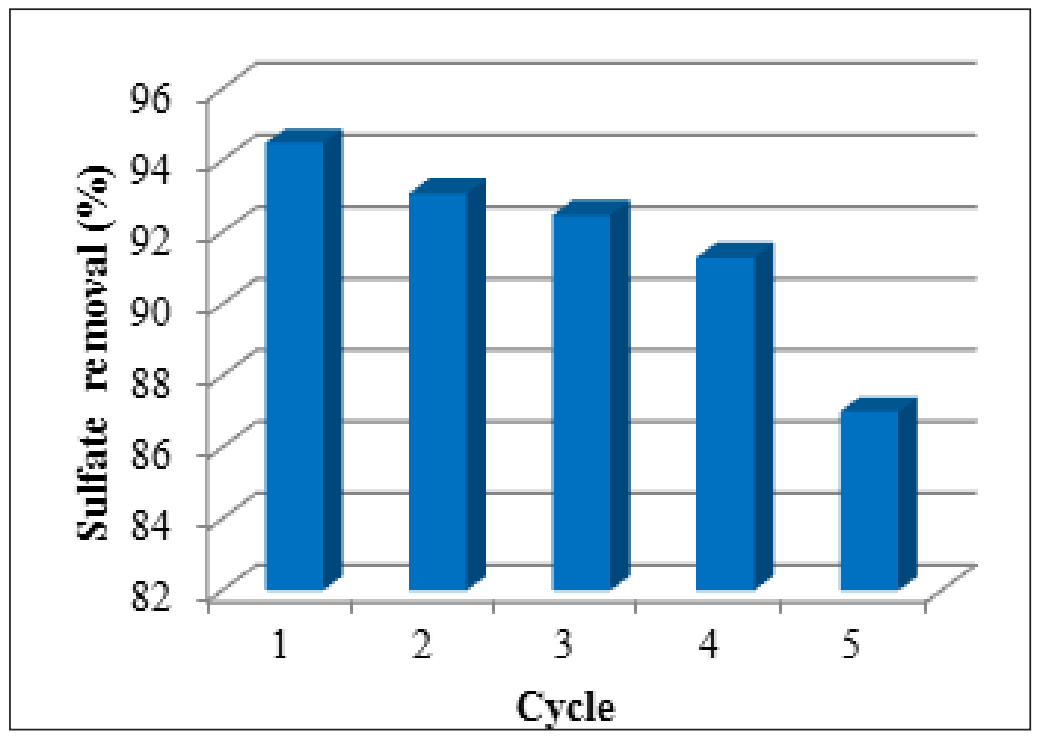

Fig. 12. The removal efficiency after five repetition usage on proposed nanosorbents.

from glass industry (Kaveh glass industry group, Saveh, Iran). The detailed characteristics of the wastewater are presented in Table 1. As can be seen, the untreated wastewater had sulfate concentration of $108 \pm 15 \mathrm{mg} \mathrm{L}^{-1}$. Therefore, removal experiments were performed by using $200 \mathrm{mg}$ of nanosorbent at $\mathrm{pH}=6.5$ and $30 \mathrm{~min}$ for contact time. It was found that the sulfate content decreased to $10 \pm 2 \mathrm{mg} \mathrm{L}^{-1}$ $(90.7 \pm 2.4 \%$ removal efficiency, $(n=3))$.

\section{Conclusions}

In this paper, Zinc (II) metalloporphyrin grafted $\mathrm{Fe}_{3} \mathrm{O}_{4}$ nanoparticle as a new and powerful sorbent for the removal of sulfate ions from aqueous media is introduced. Moreover, the sorbent showed a good efficiency in sulfate extraction and a high selectivity toward the target anion. In addition, the advantage of this product is its ease of separation

Table 1. The characteristics of glass industrial wastewater used in this study.

\begin{tabular}{ll}
\hline Anions & Value $\left(\mathrm{mg} \mathrm{L}^{-1}\right)$ \\
\hline Chloride & $228 \pm 19$ \\
\hline Fluoride & $35.5 \pm 1.2$ \\
\hline Nitrate & $8.52 \pm 0.6$ \\
\hline Sulphate & $108 \pm 15$ \\
\hline Bromide & $0.06 \pm 0.004$ \\
\hline Nitrite & $0.12 \pm 0.006$ \\
\hline
\end{tabular}

by an external magnetic field and possibility of simple recovery after washing with basic aqueous solution. Finally, the recovery of sulfate ion could be achieved, and the reuse of the sorbents is possible.

\section{References}

[1] A.J. Silva, M.B. Varesche, E. Foresti, M. Zaiat, Sulphate removal from industrial wastewater using a packed-bed anaerobic reactor, Process Biochem., 37 (2002) 927-935.

[2] P.N.L. Lens, A. Visser, A.J.H. Janssen, L.W. Hulshoff Pol, G. Lettinga, Biotechnological Treatment of Sulfate-Rich Wastewaters, Crit. Rev. Environ. Sci. Technol., 28 (1998) 41-88.

[3] C. T. Benatti, C. R. Tavares, E. Lenzi, Sulfate removal from waste chemicals by precipitation, J. Environ. Manag., 90 (2009) 504-511.

[4] R. Ghigliazza, A. Lodi, M. Rovatti, Kinetic and process considerations on biological reduction of soluble and scarcely soluble sulfates, Resour. Conserv. Recy, 29 (2000) 181-194.

[5] World Health Organization (WHO), ISBN 978924 154815 1, Guidelines for Drinking-water Quality, 2011.

[6] F. Register, National Primary and Secondary Drinking Water Regulations; Synthetic Organic Chemicals and Inorganic Chemical, Fed. Reg., 55 (1989) 30-37. 
[7] G. Muyzer, A. J. M. Stams, The ecology and biotechnology of sulphate-reducing bacteria, Nat. Rev. Microbiol., 6 (2008) 441-454.

[8] S.Y. Chang, N.Y. Zheng, C.S. Chen, C.D. Chen, Y.Y. Chen, C.R.C. Wang, Analysis of peptides and proteins affinity-bound to iron oxide nanoparticles by MALDI MS, J. Am. Soc. Mass Spectrom., 18 (2007) 910-918.

[9] X. Zhao, Y. Shi, T. Wang, Y. Cai, G. Jiang, Preparation of silica-magnetite nanoparticle mixed hemimicelle sorbents for extraction of several typical phenolic compounds from environmental water samples, J. Chromatogr. A., 1188 (2008) 140-147.

[10] C. Huang, B. Hu, Speciation of inorganic tellurium from seawater by ICP-MS following magnetic SPE separation and preconcentration, J. Sep. Sci, 31 (2008) 760-767.

[11] J.S. Suleiman, B. Hu, H. Peng, C. Huang, Separation/ preconcentration of trace amounts of $\mathrm{Cr}, \mathrm{Cu}$ and $\mathrm{Pb}$ in environmental samples by magnetic solidphase extraction with Bismuthiol-II-immobilized magnetic nanoparticles and their determination by ICP-OES, Talanta, 77 (2009) 1579-1583.

[12] B. Zargar, H. Parham, A. Hatamie, Modified iron oxide nanoparticles as solid phase extractor for spectrophotometeric determination and separation of basic fuchsin, Talanta, 77 (2009) 1328-1331.

[13] L. Sun, L. Chen, X. Sun, X. Du, Y. Yu, D. He, H. Xu, Q. Zeng, H. Wang, L. Ding, Analysis of sulfonamides in environmental water samples based on magnetic mixed hemimicelles solid-phase extraction coupled with HPLC-UV detection, Chemosphere, 77 (2009) 1306-1312.

[14] H. Parham, N. Rahbar, Solid phase extractionspectrophotometric determination of salicylic acid using magnetic iron oxide nanoparticles as extractor, J. Pharm. Biomed. Anal., 50 (2009) 5863.

[15] L. Sun, C. Zhang, L. Chen, J. Liu, H. Jin, H. Xu, L. Ding, Preparation of alumina-coated magnetite nanoparticle for extraction of trimethoprim from environmental water samples based on mixed hemimicelles solid-phase extraction, Anal. Chim. Acta, 638 (2009) 162-168.

[16] M. Faraji, Y. Yamini, A. Saleh, M. Rezaee, M. Ghambarian, R. Hassani, A nanoparticle-based solid-phase extraction procedure followed by flow injection inductively coupled plasma-optical emission spectrometry to determine some heavy metal ions in water samples, Anal. Chim. Acta, 659 (2010) 172-177.

[17] K. Moeller, J. Kobler, T. Bein, Colloidal Suspensions of Nanometer-Sized Mesoporous Silica, Adv. Funct. Mater., 17 (2007) 605-612.

[18] K.J. Klabunde, Nanoscale Material in Chemistry, Wiley-Interscience, New York, 2001.

[19] M. Faraji, Y. Yamini, M. Rezaee, Magnetic nanoparticles: Synthesis, stabilization, functionalization, characterization, and applications, J. Iran. Chem. Soc., 7 (2010) 1-37.

[20] Ch. Huang, B. Hu, Silica-coated magnetic nanoparticles modified with $\gamma$-mercaptopropyltr imethoxysilane for fast and selective solid phase extraction of trace amounts of $\mathrm{Cd}, \mathrm{Cu}, \mathrm{Hg}$, and $\mathrm{Pb}$ in environmental and biological samples prior to their determination by inductively coupled plasma mass spectrometry, Spectrochim. Acta Part B, 6 (2008) 437-444.

[21] K. Jainae, K. Sanuwong, J. Nuangjamnong, N. Sukpirom, F. Unob, Extraction and recovery of precious metal ions in wastewater by polystyrenecoated magnetic particles functionalized with 2-(3-(2-aminoethylthio)propylthio)ethanamine, Chem. Eng. J., 160 (2010) 586-593.

[22] Zh. Yong-Gang, Sh. Hao-Yu, P. Sheng-Dong, H. Mei-Qin, J. Hazard. Mater., 182 (2010) 295.

[23] X. Wang, L.Wang, X. He, Y. Zhang, L. Chen, A molecularly imprinted polymer-coated nanocomposite of magnetic nanoparticles for estrone recognition, Talanta, 7 (2009) 327-332.

[24] .P.D Beer, .PA. Gale, Anion Recognition and Sensing: The State of the Art and Future Perspectives, Chem. Int. Edu., 40 (2001) 486-516.

[25] A. Bianchi, K. Bowman-James, E. Garcia-Espan., Supramolecular Chemistry of Anions, Wiley/VCH, 1997.

[26] J.T. Mitchell-Koch, M. Pietrzak, E. Malinowska, M. E. Meyerhoff, Aluminum(III) Porphyrins as Ionophores for Fluoride Selective Polymeric Membrane Electrodes, Electroanal., 18 (2006) 551557 .

[27] T. Poursaberi, M. Hassanisadi, K. Torkestani, M. Zare, Development of zirconium (IV)metalloporphyrin grafted $\mathrm{Fe}_{3} \mathrm{O}_{4}$ nanoparticles for efficient fluoride removal, Chem. Eng. J, 189 (2012) 117-125. 
[28] T. Poursaberi, M. Karimi, M. Hassanisadi, H. Sereshti, Magnetic removal of nitrate ions from aqueous solution using amino-silica coated magnetic nanoparticles modified by oxovanadium(IV) porphyrin, J. Porphyrins Phthalocyanines, 17 (2013) 359-366.

[29] J. G. Erdman, V. G. Ramsey, N.W. Kalenda, W. E. Hanson, Synthesis and Properties of Porphyrin Vanadium Complexes, J. Am. Chem. Soc., 78 (1956) 5844-5847.

[30] X.L. Zhao, Y.L. Shi, Y.Q. Cai, S.F. Mou, Cetyltrimethylammonium Bromide-Coated Magnetic Nanoparticles for the Preconcentration of Phenolic Compounds from Environmental Water Samples, Environ. Sci. Technol., 42 (2008) 12011206.

[31] R.B.S. Merrifield, J. Am. Chem. Soc. 2149 (1963) 85.

[32] V.V.Egorov, E.M.Rakhman'ko, A.A.Rat'ko, Metalloporphyrin-Based Anion-Selective Electrodes with Unusual Selectivity, J. Anal. Chem., 57 (2002) 46-53.

[33] K. M. Morehouset and P. Neta, J. Phys. Chem., 18 (1984) 88 .

[34]Y. Kang, C. Lutz, S.A. Hong, D. Sung, J.S. Lee, J.H. Shin, H. Nam, G.S. Cha, M.E. Meyerhoff, Development of a Fluoride-Selective Electrode based on Scandium(III) Octaethylporphyrin in a Plasticized Polymeric Membrane, Bull. Korean Chem. Soc., 31 (2010) 17-29. 